\title{
Correlation between Heredity Factor and Menarcheal Age among Adolescent Aged 9-15 Years 0ld
}

\author{
Nurul Khotimah, ${ }^{1}$ R.M. Ryadi Fadil, ${ }^{2}$ Haryono Tansah $^{3}$ \\ ${ }^{1}$ Faculty of Medicine Universitas Padjadjaran, ${ }^{2}$ Department of Child Health Faculty of Medicine \\ Universitas Padjadjaran/Dr. Hasan Sadikin General Hospital Bandung, ${ }^{3}$ Department of \\ Biochemistry Faculty of Medicine Universitas Padjadjaran
}

\begin{abstract}
Background: Menarche is a sign of maturity of the female reproductive function. It is influenced by many factors, such as heredity, general health status, nutrition, and socioeconomic status. The purpose of this study is to determine the correlation of heredity and menarcheal age.

Methods:This study was a cross-sectional analytic study conducted from September-October 2014 in Bandung using a multi-stage sampling technique and it was conducted in twelve elementary schools and junior high schools. A total of 123 subjects were included in this study. The instrument of this study was questionnaire containing menarcheal age of subject, older sister, biological mother, and maternal grandmother. The data were analyzed using Spearman correlation and linear regression test with the level of significance was determined at $\mathrm{p}<0.05$.

Results: Among 123 data, the majority of subjects had experienced menarche at the age of $11(39 \%)$ and 12 years $(36.6 \%)$ with an average of 11.46 years old. Based on the Spearman correlation and multiple linear regression tests, there was a correlation between heredity and menarcheal age. $(\mathrm{P}=0.00)$.

Conclusions: There is a correlation between heredity and menarcheal age, with the highest correlation is between subject's and older sister's menarcheal age.
\end{abstract}

Keywords: Adolescent, heredity, menarche

\section{Introduction}

In times of growth, human will grow from fetuses, infants, children, and adolescents to adults. The transition from childhood to adulthood is called puberty. One of the changes that will happen is the emergence of signs of sexual maturation and reproductive function, which is marked by menarche or first menstruation. Physically, menarche is characterized by bleeding from vagina due to sloughing of the endometrial lining. Menarche usually occurs one to two years after the growth spurt. ${ }^{1}$ The age range of menarche adolescents in Indonesia is 9-18 years old. ${ }^{2}$

Factors that influence menarche consist of endogenous and exogenous factors. The examples of endogenous factors are genetics and health status, while the exogenous factors are the nutritional status and socioeconomic condition. ${ }^{3,4}$ Many studies were studying the relationship between exogenous factors and menarche but the study on the relationship between heredity as one of the genetic manifestations and the age of menarche is still rare. On the other hand, in determining a person's menarcheal age, it is easier to predict from heredity.

Based on the study in the United Kingdom, there is a significant relationship between heredity and menarcheal age. The study involved three generations, the grandmother, mother, and the subject. The results of significance for all three variables are highly significant. However, there is an increase in the average of menarcheal age. ${ }^{5}$ Not only in the United Kingdom ${ }^{6}$, a similar study was also conducted in Australia, which the subjects are monozygotic twin, dizygotic twin, and siblings. The most significant result was found in monozygotic twin. ${ }^{7}$ It is indicated that there is an influence of heredity in the menarcheal age.

Based on the theoretical facts and the results of previous studies above, the relationship

Correspondence: Nurul Khotimah, Faculty of Medicine, Universitas Padjadjaran, Jalan Raya Bandung-Sumedang Km.21, Jatinangor, Sumedang, Indonesia, Phone: +6287729166628 Email: nlkhotimah@gmail.com 
between heredity and menarcheal age among adolescent aged between $9-15$ years old in Bandung was interesting to study. Selection of subjects due to menarche occurs largely in the age range $9-15$ years old. ${ }^{2}$

\section{Methods}

This study was a cross-sectional study conducted from September-October 2014 in elementary school and junior high school students in Bandung, West Java, Indonesia. A total of 123 data were collected by multistage random sampling technique. First, Bandung was divided into six administrative regions. Furthermore, the selection of one elementary school and one junior high school was randomly based on the data from the Education Board of Bandung in each region. After that, proportional random sampling was used to select the subject of the 12 selected schools. Inclusion criteria for this study were (1) adolescents aged between 9-15 years old in the selected schools who attended and were voluntarily engaged in the study, and (2) older sister, biological mother, and maternal grandmother of the subject who remember their menarcheal age. Exclusion criteria were (1) subjects with a chronic disease or hormonal disorders, and (2) subjects taking hormonal drugs.

The instrument of this study was a validated questionnaire containing the identity, health status, and menarcheal age of subjects, subjects' older sister, biological mother, and maternal grandmother. The collected data were entered into the computer using Microsoft Excel 2007 and SPSS (version 20) software. Furthermore, the data were analyzed using the Spearman correlation test, with a significance value at $\mathrm{p}<0.05$. After that, the data were analyzed using multiple linear regression to determine the magnitude of the changes in the subject's menarcheal age if there is a change in heredity. The test was performed by a model calculation: $Y=a+b_{1} X_{1}+b_{2} X_{2}+b_{3} X_{3}$

$\mathrm{Y}=$ dependent variable $\mathrm{a}=$ constant

b1, b2, b3 = regression coefficients

$\mathrm{X} 1, \mathrm{X} 2, \mathrm{X} 3$ = independent variables

Ethical approval was obtained from the Health Research Ethics Committee of Universitas Padjadjaran, Bandung . Informed consent was also obtained from the National Unity and Community Development of Bandung, Education Board of Bandung, and school authorities.

\section{Results}

The data were then collected from twelve elementary schools and junior high schools

Table 1 Distribution of Subject's Menarcheal Age

\begin{tabular}{lcccc}
\hline \multicolumn{1}{c}{ Variable } & Subject & Sister & Mother & Grandmother \\
\hline Menarcheal age & & & & \\
9 & $2(1.6)$ & $5(4.1)$ & - & - \\
10 & $14(11.4)$ & $28(22.8)$ & $2(1.6)$ & $2(1.6)$ \\
11 & $48(39)$ & $54(43.9)$ & $8(6.5)$ & $4(3.3)$ \\
12 & $45(36.6)$ & $33(26.8)$ & $50(40.7)$ & $47(38.2)$ \\
13 & $13(10.6)$ & $2(1.6)$ & $44(35.8)$ & $40(32.5)$ \\
14 & $1(0.8)$ & $1(0.8)$ & $13(10.6)$ & $22(17.9)$ \\
15 & - & - & $5(4.1)$ & $7(5.7)$ \\
16 & - & - & $1(0.8)$ & - \\
17 & - & - & - & $1(0.8)$ \\
Total & 123 & 123 & 123 & 123 \\
Menarcheal age & & & & \\
Mean & 11.46 & 12.02 & 12.63 & 12.83 \\
Median & 11 & 12 & 13 & 13 \\
Minimum-maximum & $9-14$ & $10-15$ & $10-16$ & $10-17$ \\
\hline
\end{tabular}


Table 2 Correlation between Subject's Menarcheal Age and Older Sister's, Biological Mother's, and Maternal Grandmother's Menarcheal Age

\begin{tabular}{cccc}
\hline Correlation & $\begin{array}{c}\text { Older Sister's } \\
\text { menarcheal age }\end{array}$ & $\begin{array}{c}\text { Biologic Mother } \\
\text { menarcheal age }\end{array}$ & $\begin{array}{c}\text { Maternal grandmother's } \\
\text { menarcheal age }\end{array}$ \\
\hline Subject's menarcheal age & r: 0,522 & r: 0.207 & r: $\mathbf{0 . 2 1 6}$ \\
& p: 0.00 & p: 0.021 & p: $\mathbf{0 . 0 1 7}$ \\
\hline
\end{tabular}

of the six regions of Bandung city. The schools were SDN (Public Elementari School) Asmi, SDN Banjarsari, SDN Cijawura, SDN Ciujung, SDN Sejahtera, SDN Ujung Berung, SMP Negeri (Public Junior High School) 1, SMP Negeri 2, SMP Negeri 8, SMP Negeri 11, SMP Negeri 14, and SMP Negeri 18. From twelve schools, there were 238 children who met the inclusion criteria in this study. A total of 115 children did not fill the questionnaire completely, so only 123 children who wereincluded in this study.

The mean of subject's menarcheal age was earlier than the mean of older sister's, biological mother's, and maternal grandmother's menarcheal age. The earliest of menarcheal age was 9 years old, meanwhile the latest was 17 years old.

After that, the data were analyzed using Kolmogorov-Smirnov and Shapiro Wilk test to know the distribution of the data. The data were not normally distributed, so they were analyzed using Spearman correlation test. The result was shown at table 2 .

Based on Spearman test, there was correlation between heredity and menarcheal age. The highest correlation was found between subject's and older sister's menarcheal age, while the lowest was found between subject and biological mother. All correlation among variables was positive so if one variable was increasing, the other variables would be increased.

To determine the correlation between heredity combinations of older sister's, biological mother's, and maternal grandmother's menarcheal age and subject's menarcheal age, multiple linear regression was conducted. The result of this correlation was 0.3 . The correlation was positive but it had a low correlation. Based on data analysis, the data had $\mathrm{p}$ value $<0.05$ so there was a correlation between subject's menarcheal age and heredity that were taken from older sister's, biological mother's, and maternal grandmother's menarcheal age.

To determine the changes in subject's menarcheal age based on heredity, multiple regression tests were conducted. Based on the results of the data analysis, the regression result between heredity and menarcheal age showed was 6.017 , b1 was 0.644 , and b2 was -0.251 . Maternal grandmother was not applied to regression model due to level of significance $>0.05$. Therefore, regression model was obtained:

Subject's menarcheal age $=6.017+0.644$ (older sister's menarcheal age)-0.251(biological mother's menarcheal age)

\section{Discussions}

The mean of menarcheal age in Bandung was earlier (11.46) than national Indonesian survey conducted in 2010, which was 12.96 years old. ${ }^{2}$ The mean of menarcheal age in Bandung is also lower than the mean of menarcheal age in United Kingdom ${ }^{6}$ (12.7), India $^{8}$ (12.43), and $\mathrm{Nepal}^{9}$ (12.85). The differences among those results are caused by heredity and environment factors. ${ }^{10}$

The mean of subject's menarcheal age was lower than older sister's, biological mother's, and maternal grandmother's menarcheal age. The similar result was also found in the study conducted in the United Kingdom ${ }^{6}$ by Morris (2011) but the mean difference of menarcheal age in this study was higher than United Kingdom. The mean differences of menarcheal age are caused by nutrition intake, physical activity, and psychological state. ${ }^{11}$

Based on Spearman correlation and multiple linear regression tests, there was a correlation between heredity and menarcheal age. The similar results were found in the study conducted in Australia $^{5}$, United Kingdom ${ }^{6}$, and Iran ${ }^{13}$. The heredity factor is caused by influence of Sterol Regulatory Element Binding Protein (SREBP), Cytochrome P450 family 19 subfamily A polypeptide 1 (CYP19A1), Cytochrome P450 family 17 (CYP17), Estrogen Receptor $\alpha$ (ESR $\alpha$ ), and GnRH receptor (GnRHR) gene that will affect quantities and activities of steroid hormones, such as GnRH, estrogen, and progesterone that stimulate process of menarche. ${ }^{7,14,15}$ However, this study 
did not discuss about those genes. The highest correlation was found between subject's and older's sister menarcheal age. This result revealed that not only heredity could influence menarcheal age, but also other factors, such as nutritional intake and health condition.?

The correlation between subject's and biological mother's menarcheal age was the lowest correlation. This result is caused by other factors, such as nutritional intake before puberty, which could affect menarcheal age. ${ }^{16}$ Therefore, heredity is dominant in non-obese children. ${ }^{16}$

The limitations of this study were limited of time and budget also less of subject's enthusiasm in some regions. The used study design was not suitable so it could not eliminate the confounding factors, such as nutritional intake and psychological state. This was caused by difficulty to assess those factors and high bias. Recall information about menarcheal age could lead to information bias.

Recommendations based on limitation of this study are increasing size and enthusiasm of subjects, and using prospective cohort design to reduce information bias and eliminate confounding factors.

Based on data analysis and discussion above, the mean of menarcheal age among adolescent aged $9-15$ years old in Bandung is 11.46 years old. There is a correlation between heredity and menarcheal age, with the highest correlation is between subject's and older sister's menarcheal age.

\section{References}

1. Cromer B. Menstrual problem. In: Kliegman RM, Stanton BF, St. Geme III JW, Schor NF, Behrman RE, editors. Nelson textbook of pediatrics. $19^{\text {th }}$ ed. Philadelphia: Elsevier; 2011. p. 1208.

2. Jose RL Batubara, Frida Soesanti, van de Waal HD. Age at menarche in Indonesian girls: a national survey. Acta Med Indones. 2010;42(2):78-81.

3. Goyal R, Mehta P, Kaur G. Nutritional status and menarche in adolescents of Punjab. J Life Sci. 2012;4(1):63-6.

4. Elshiekh M, Mohammed AMA. Influence of socioeconomic status in the age at menarche and duration of menstrual bleeding. Mat Soc Med. 2011;25(4):195-9.
5. Anderson CA, Duffy DL, Martin NG, Visscher PM. Estimation of variance components for age at menarche in twin families. Behav Genet. 2007;37:668-77.

6. Morris DH, Jonesa ME, Schoemakera MJ, Ashworthb A, Swerdlowa AJ. Familial concordance for age at menarche: analyses from the breakthrough generations study. Paediatr Perinat Epidemiol. 2011;25(3):306-11.

7. Styne DM, Grumbach MM. Puberty. In: Henry M. Kronenberg M, Shlomo Melmed M, Kenneth S. Polonsky M, P. Reed Larsen M, FACP, FRCP, editors. Williams textbook of endocrinology. $12^{\text {th }}$ ed. Philadelphia: Elsevier; 2011. p. 969.

8. Khatoon T, Verma AK, Kumari R, Rupani $\mathrm{R}$, Singh M, Rizvi A. Age at menarche and affecting bio-social factors among the girls of Lucknow, Uttar Pradesh. J Indian Acad Forensic Med. 2011;33(3):221-3.

9. Sunuwar L, Saha C, Dhungel KU. Age at menarche of subpopulation of Nepalese girls. Nepal Med Coll J. 2010;12(3):183-6.

10. Styne D. Puberty. In: Gardner DG, Shoback D, editors. Greenspan's basic \& clinical endocrinology. 9th ed. New York: Mc-Graw Hill; 2011. p. 454.

11. Joinson C, Heron J, Lewis G, Croudace T, Araya R. Timing of menarche and depressive symptoms in adolescent girls from UK cohort. Brit J Psychiat. 2011;198:17-23.

12. Tehrani FR, Mirmiran P, Zahedi-Asl S, Nakhoda K, Azizi F. Menarcheal age of mothers and daughters: Tehran lipid and glucose study. East Mediterr Health J. 2010;16(4):391-5.

13. Karapanou O, Papadimitriou A. Determinants of menarche. Reprod Bio Endocrinol. 2010;8:115-23.

14. Dvornyk V, Waqar-ul-Haq. Genetics of age at menarche: a systematic review. Hum Reprod Update. 2012;18(2):198-210.

15. Epplein M, Novotny R, Daida Y, Vijayadeva V, T. Onaka A, Marchand L. Association of maternal and intrauterine characteristics with age at menarche in a multiethnic population in Hawaii. Cancer Causes Control. 2011;21(2):259-268.

16. Ersoy B, Balkan C, Gunay T., Egemen A. The factors affecting the relation between the menarcheal age of mother and daughter. Child Care Health Dev. 2005;31(3): 303-8. 